Article

\title{
What Is Genealogy? An Anthropological/Philosophical Reconsideration
}

\author{
Bruce M. Knauft \\ Department of Anthropology, Emory University, Atlanta, GA 30322, USA; bruce.knauft@emory.edu \\ Academic Editor: Philip Kretsedemas \\ Received: 8 October 2016; Accepted: 29 December 2016; Published: 17 January 2017
}

\begin{abstract}
Genealogical analysis in the present begs reconsideration of Nietzschean and Foucauldian precursors in relation to the ethical subject position of the subject, on the one hand, and application to concrete contexts of lineal connection asserted diversely across cultural time and space, on the other. This paper considers how the relation between genealogy and history has emerged in anthropologically relevant ways since Foucault, including comparisons and contrasts with selected recent philosophical treatments, with implications for contemporary understandings of subversion, resistance, and the critical assessment of truth claims, including concerning veridiction itself. Developments in anthropology resonate with many features associated with genealogical analysis in Foucault's latter works. In selected respects, the subversive process of problematizing received accounts of historical and cultural development articulates with the subversive process of ethnographic investigation, whereby received Western or other assumptions are defamiliarized by being thrown into contrastive cultural relief. The more general relation between genealogical analysis and the critical understanding of modernity is discussed, including in relation to contemporary political genealogy and 'inter-genealogical' analysis.
\end{abstract}

Keywords: genealogy; ethnography; subversion; modernity; Foucault; Nietzsche

\section{Introduction}

Genealogies do not take up those problems that come with supposed solutions readily apparent. Genealogies are concerned, rather, with submerged problems that condition us without our fully understanding why or how. Despite their depth, these problems are also right at the surface insofar as they condition us in our every action, our every quality, our thought, our every sadness and smile. The point of a genealogy is not just to denaturalize but to show how that which is so easily taken as natural was composed into the natural-seeming thing that it is.

([1], pp. 1, 129; ellipses omitted)

If the concept of modernity was first promulgated in print by Baudelaire in le Figaro in 1863 [2], the contra-modern notion of genealogy followed in Nietzsche's On the Genealogy of Morals just fourteen years later, in 1877. These complementary problematics have developed in close tandem since their initial formulation. Now almost a century and a third following, in the aftermath of both modernist and post-modernist intellectual eras and well in to the 21st century, it seems hard to adequately engage a critically trenchant consideration of genealogy's own modern genealogy apart from considering the massive impact on our contemporary awareness of Foucault, founder of an arguably new and highly influential mode of discursivity ([3], p. 26). In the present context, this includes his interpretation of the Nietzschean concept of genealogy, especially in Foucault's "Nietzsche, Genealogy, History" [4].

The recent sources that Philip Kretsedemas considers in his effective editorial for Genealogy as a new journal draw greatly on a Nietzschean/Foucauldian legacy or lineage despite or perhaps all the 
more because this line of connection is not explicitly mentioned or cited in his text. His question for this issue, "What is Genealogy?" is itself one that Foucault himself could reasonably have posed (along with "What is an Author?" "What is Enlightenment?" and so forth). For purposes of the present paper, I take the Nietzschean-Foucauldian line of genealogical connection as a point of departure to address Kretsedemas' question [5,6].

Anthropology, which is the line of intellectual descent by which I myself have been most professionally disciplined, has been both blessed and cursed by being the scholarly field most concerned with genealogy as an academic pursuit. Anthropology's story about itself has often included the statement that amid the myriad topics that anthropology shares or overlaps with other scholarly disciplines-politics, religion, economics, material culture, art, linguistics, psychology, history, philosophy, and so on-kinship is the topic most exclusive to anthropology. In his classic work on the subject, Fox states simply, "Kinship is the central discipline of Anthropology" ([7], p. 10).

Anthropological studies of kinship are renowned perhaps most of all for documenting the culturally constructed as opposed to the ostensibly natural dimensions of genealogical relationships. Kinship genealogy is not a biogenetic 'given' but a complex social process whereby some taken-as-natural forms of culturally attributed relatedness-including through patrilineal, matrilineal, bilateral, ambilineal, or double descent-are attributed and believed to be completely innate, biological, and real. Legion in cultural anthropology are the diverse principles through which different cultural ways of configuring genealogies are each made to seem completely natural [8-10].

On the other hand, perhaps not coincidentally, anthropology is also one of the academic fields most deeply critical of its own disciplinary genealogy ([11-13]; contrast [14-16]; [17]; see [18]). My present contribution does not presume to review contemporary studies of kinship and descent/genealogy in anthropology $[19,20]$, nor to suggest how the study of kinship and descent is now being rediscovered in amid glocal flows of people, ideas, images, and technologies-including new modalities of kinship, marriage, and reproduction ([21-24], cf., [25]). Nor do I attend to the profound error of truth claims in the study of descent and kinship that occupied early anthropological scholarship [26] —including in the work of McLennan [27,28]; Maine [29,30], and Morgan [31,32] during the same general period as Baudelaire and Nietzsche were writing. While I do consider the relevance of contemporary 'genealogy studies', just in passing, my primary purpose is to consider how the relation between genealogy and history has emerged in anthropologically relevant ways before and since Foucault, and what this suggests for our contemporary understanding of causation, subversion, and the critical assessment of truth claims, including the more general assumption of veridiction itself.

As such, this paper investigates the relationship between genealogical analysis and the scholarly field of anthropology, including in relation to philosophic studies as well as, to a lesser extent, the human sciences generally. At one level, genealogy, as opposed to history, is simply an alternative way of considering the relationship between entities over time- not in a relationship of assumed causation, but in an alternative or bare factual sequence of what preceded and succeeded what. To summarize the argument that follows, anthropology has long cultivated sensibilities that resonate with genealogical analysis of a Nietzschean or Foucauldian kind. Specifically, anthropology as a field-and ethnology and ethnography as methods—share with Nietzschean/Foucauldian genealogy both an interest in history and a subversive tendency to unearth and highlight counter-normative connections that defamiliarize and relativize Western understanding of cultures and histories, including our own. On the other hand, some features of genealogical analysis in a Nietzchean or Foucaudian perspective emerge as problematic for anthropology, including the potential for elitist proclamation of superordinate truths/values in the case of Nietzsche, and the potential for theoretically detached (a-)politicism in the case of Foucault. Concerning these same points, ethical commitments longstanding in anthropology have become increasingly explicit and robust in recent years. At present, these combine increasingly with anthropologists' interest in the causes and conditions that produce human suffering and exploitation, on one hand, and, on the other, understanding and appreciating the creative ways by which people combat suffering or anomie by resilient assertions of meaning, dignity, positive 
value and/or goodness (see [33]). To date, anthropology has been informed rather than transformed by Nietzschean or Foucauldian genealogical analysis, but there is strong and potentially increasing synergy between them. This is especially the case in areas such as the critical understanding of neoliberal modernity, its contemporary politics, and it emergent forms of political or politicized affiliation and activism. My presentation closes with a discussion of the hoped-for benefits as well as selected limitations of critical genealogy as an analytic method.

\section{POMO, or No Mo' POMO?}

In the anthropology of the late 1980s and 1990s, drawing on Foucault but also on deconstruction, hermeneutics, post-Marxism, and reflexive critiques of anthropological writing, anthropology's method as well as its history were subject to strong cultural critique, or, as Marcus and Fischer [34] put it in their subtitle, "an experimental moment in the human sciences". Debates raged over the salience, excesses, or potential ridiculousness of postmodernism and its impact on ethnographic writing, including the threat of an "over the Clifford" anthropology [12,13].

Increasing awareness of Foucault's work both galvanized and problematized these debates, since Foucault seemed at turns to be a paragon of a boldly new epistemic formulation and an arch critic of the valid possibility of any such formulation. That Foucault's initial major introducer, editor, and interpreter to the English-speaking world, Paul Rabinow, was an accomplished and respected Francophile anthropologist increased Foucault's impact and relevance while 'anthropologizing' the first waves of his perception by English-speaking scholars. This included an emphasis on historical and cultural specificity in Foucauldian genealogies and their relevance for alternative peoples and cultures. At larger question, as I put it in the mid-90s, was how anthropology-in the midst of postmodernism, post-colonialism, post-structuralism, post-Marxism, and post-feminism—could and should push "past the posts" [18,35].

A significant part of this question has been political and ethical. As postmodernism refused established master narratives, it also dismantled received ethical as well as objectivist or scientific cartographies of justification. In this vacuum, were assertions of value merely reflections of an individual's will to power? At the time, a number of committed Leftist intellectuals felt Foucault was tepid and stand-offish for not publicly and actively associating with the Communist or at least the Socialist Party, for being highly engaged in male sado-masochism without being effectively out of the Gay closet, and for looking askance at feminism —while, on the other hand, being uncomfortably partial to Maoist anarchism and lending intellectual approval to brutal atrocities in the Iranian revolution in 1979 [36,37]. Foucault was an avowedly mercurial or even contradictory persona; “Do not ask me who I am and do not ask me to remain the same: leave it to our bureaucrats and our police to see that our papers are in order" ([38], p. 126). Foucault's powerful championing of Nietzschean sensibilities in the figuration of genealogies elevated these stakes, since Nietzsche could be taken as a propounder of male domination and misogyny, anti-semitic, hyper-elitist, and pre-occupied with Greco-Aryan purity-if not providing an intellectual precursor to Nazism. Like Nietzsche, Foucault was resolutely Western in outlook, going back from European culture to the ancient Greeks but never engaging colonialism or non-Western cultures in a significant way. As Edward Said ([39], p. 9) suggested of Foucault, "The most striking of his blind spots was, for example, his insouciance about the discrepancies between his basically limited French evidence and his ostensibly universal conclusions. Moreover, he showed no real interest in the relationships his work had with feminism or postcolonial writers facing problems of exclusion, confinement, and domination. Indeed, his Eurocentrism was almost total, as if history itself took place only among a group of French and German thinkers".

Since about the mid-1990s, however, Foucault's intellectual contributions in relation to his personal life have been increasingly appreciated, including in biographies that provide further accounts of his intellectual and social activism in France and in relation to foreign peoples and causes [40-42]. Greater appreciation has also developed concerning Foucault's style of intellectual life as a kind of engaged philosophical exercise—an askesis—-to develop deeper awareness of freedom and its limits in relation 
to received notions if self-relationship and thought [43]. Concerning alternative sexuality, prominent intellectual David Halperin published a self-described gay hagiography entitled, Saint Foucault [44].

Somewhat surprising from an anthropological perspective, the Western narrowness and potential ethical problems of Nietzschean/Foucauldian genealogies are little addressed in prominent recent philosophical considerations [1,5,6,45-47]. Koopman does suggest how Nietzsche's use of genealogy is 'subversive' and Foucault's is 'problematizing', and the latter perspective in particular is elaborated with highly useful nuance and refinement. But the question of how and in what ways genealogy has been or could be co-opted to support highly problematic ethical, moral, and political stances is, on the whole, not greatly addressed in philosophical treatments.

\section{Genealogy per se}

It may be useful in hindsight to parse selective dimensions of genealogy à la Nietzsche and Foucault-and to identify productive points of departure from their more strident implications. As is also the case with Foucault, it can be useful to distinguish the style and structure of Nietzsche's critique of received modes of establishing history or assuming truth from his proactive assertions or affirmations concerning what should replace these. In a sense, genealogical analysis is better at recasting and refusing received assumptions than at proposing new master narratives-or, to put it more generally, it is better at refusing received assumptions of historical value and meaning than at attempting a new Hegelian synthesis from a presumed higher or more objective or more logically intelligent authorial position. In this regard, what is particularly strong and useful in Nietzsche's notion of genealogy is his excoriating exposure of received assumptions concerning historical development.

In his On the Genealogy of Morals, Nietzsche [48] emphasizes the general failure of thinkers to see the development of moralistic truth claims over time as an objective sequence-rather than itself a tale of moral improvement (or decline). These tales are by nature a selectively reconstructed sequence permeated with taken-for-granted assumptions of authorial truth. And these, in turn, reflect and encode structures of power and domination. Nietzsche writes, "philosophers, you see, are by no means reliable, honest witnesses and judges of the value of the ascetic ideal. They think of themselves-what is the 'saint' to them? They think only of that which to them is most indispensable..." ([48], p. 94, emphases original). Though Nietzsche is in formal ways the obverse of Marx-championing an ur-aristocracy rather than the plebs, the proletariat-both Nietzsche and Marx insist on the objective determination of morality as bequeathed over time, and both find this developmental core to be the essential interest of elite power.

For Nietzsche, however-as also for Foucault-this critique extends not only to religion to but also to science. Debunking the notion of an agentless cause, Nietzsche asserts that, "The scientists fail to improve matters when they say, force moves, force causes, and so on. Our science is still, in spite of being cool and calculating, a dupe of the tricks of language, and has never rid itself of that superstitious changeling 'the subject'. What wonder, then, if the hidden, deep-seated, smouldering passions of vengeance and hatred exploit their belief for their own ends ..." ([48], p. 33). Nietzsche is also highly critical of the teleology of evolutionist thinking that presumes a progression between genealogical sequences or stages.

[T] he 'evolution' of a thing, of a custom, of an organ, is anything but its progression towards some end; still less is it a logical progression attained in the most direct manner and with the minimum expenditure of energy and cost; it is, rather, the succession of processes of subjugation, more or less profound, more or less mutually independent, which are directed upon the thing itself; it is, further, the resistance encountered in each case, the attempted adaptations and alterations of form for the purpose of defense and reaction, and, further, the results of successful counter-measures... ([48], p. 63)

And again, as if in a nod to Science and Technology Studies (STS) today, 
What is science hiding today? How much, at any rate, is it supposed to be hiding? The diligence of our best scholars, their stupendous industry, burning the candle at both ends-the mastery of their handiwork, isn't all of that merely an effort to conceal something from themselves? Science serves as a narcotic... for they are dazed and unconscious men who have but one fear-regaining their consciousness. We 'men of science' have grown more and more suspicious of all kinds of believers ... but for that very reason, we do deny that faith proves anything.... [T] hey stand too close-this ideal is simply their ideal as well... they themselves are its most intellectualized offspring, its most front-line troops and scouts, its most insidious, delicate, and elusive form of seduction - if I am ever to solve an enigma, let it be this one: for some time past there have been no freethinkers, for they still believe in truth. ([48], pp. 132-34, emphases original)

From a contemporary vantage point, Nietzsche reaches his limit point when he bases his critique of values on the assertion of a hyper-elite uncompromised truth (see [49], p. xx). In common with many, if not most, versions of Marxism, his critique of received understandings and ideologies is much more powerful and convincing than his positive assertions concerning what should replace them.

Nietzsche's genealogical critique of history (and historiography) does draw on his deep scholarly training in etymology and philology (see [46], Chs. 1,2). And he emphasizes that the genealogy of morals hinges on "documentary evidence, that which is capable of definite proof, that which has actually existed, or, to put it briefly, the whole of that long hieroglyphic script (so hard to decipher) in which is inscribed the past history of human morals..." ([48], p. 9). But Foucault develops such points much more strongly and consistently - and avoids essentialist claims of holding a subject position from which an unmediated or purer basis for asserting truth is possible. In these regards, Foucault's employment of genealogy seems significantly more nuanced, cautionary, and subtle.

[G]enealogy retrieves an indispensable restraint: it must record the singularity of events outside of any monotonous finality; it must seek them in the most unpromising places, in what we tend to feel is without history-in sentiments, love, conscience, instincts; it must be sensitive to their recurrence, not in order to trace the gradual curve of their evolution, but to isolate the different scenes where they engaged in different roles.... Genealogy... requires patience and a knowledge of details, and it depends on a vast accumulation of source material.... In short, genealogy demands relentless erudition... [I]t rejects the metahistorical deployment of ideal significations and indefinite teleologies. It opposes itself to the search for 'origins'. ([4], pp. 76-77)

Ultimately for Foucault, genealogy supplies "the history of an error we call truth" ([4], p. 81). More generally, this paves the way for a history of what he elsewhere calls "regimes of veridiction" ([50], p. 35; cf., [51]): “Obviously, a history of truth should not be understood in the sense of a reconstruction of the genesis of the true through the elimination or rectification of errors; nor a history of the true which would constitute a historical succession of rationalities established through the rectification or elimination of ideologies. Nor would this history of truth be the description of insular and autonomous systems of truth. It would involve the genealogy of regimes of veridiction..."

In political and ethical as well as in philosophic and intellectual terms, this situates Foucault, in contrast to Nietzsche, outside established proponents for or agonists against particular kinds of truth claims at the level of content. This vouchsafed his ability to champion the openness of the unthought and the unsaid against strictures of category and ideology propounded by practically any political or ethical point of view, including a scientific one.

Genealogies are ... not positivistic returns to a form of science that is more attentive or more accurate. Genealogies are, quite specifically, antisciences. It is not that they demand the lyrical right to be ignorant, and not that they reject knowledge or invoke or celebrate some immediate experience that has yet to be captured by knowledge. This is not what they are 
about. They are about the insurrection of knowledges. Not so much against the contents, methods, or concpets of a science; this is above all, primarily, an insurrection against the centralizing power-effects that are bound up with the intitutionaliation and workings of any scientific discourse organized in a society such as ours. ([48], p. 9)

Thus, for Foucault,

Genealogy does not pretend to go back in time to restore an unbroken continuity that operates beyond the dispersion of forgotten things; its duty is not to demonstrate that the past actively exists in the present... Genealogy does not resemble the evolution of a species and does not map the destiny of a people. On the contrary, to follow the complex course of descent is to maintain passing events in their proper dispersion; it is to identify the accidents, the minute deviations-or conversely, the complete reversals-the errors, the false appraisals, and the faulty calculations that gave birth to those things that continue to exist and have value for us; it is to discover that truth or being does not lie at the root of what we know and what we are, but the exteriority of accidents. ([4], p. 81)

\section{Modern Is as Modern Does}

It is patent that Foucault's notion of genealogy as infused selectively from Nietzsche has enormous power to recast, upend, and render problematic — though not to 'transcend' - existing accounts of historical progression, influence, and either progress/development or decline/devolution. Though the intellectual critique of modernity reached its height in the 1990s, as if scorching the earth of master narratives of progress, the practical world has since proven nowhere near as pliable. Like the forecasted decline of religion against the rise of modern secularism-by intellectuals during the early twentieth century-the forecasted death of modern neoliberal progress as a deeply embraced value-by intellectuals at the turn to our present century-has proven vastly overstated.

Today, plans and paradigms of modernist economic development-based ubiquitously on presumed sequences of progress and improvement-are so globally hegemonic as to be practically omnipresent, the air we breathe. They nip at the heels of even the most refractory political regimes such as ISIS in the Mid-East and Kim Jong-Il in North Korea-not to mention in the US under a Trump presidential administration. In my own development work in a range of countries across the global south (www.bruceknauft.com -> engaged anthropology), burgeoning plans for modernist economic development are not just the rule but the coin of the realm, from Ecuador to India, from Liberia or Congo to Mongolia, Myanmar, or Papua New Guinea (e.g., [52]). Even as these strategic master plans of modern improvement consistently founder and typically fail, they show no sign of letting up or being fundamentally replaced. Even in the most remote areas of the Papua New Guinea rainforest that I have revisited since the 1980s, burgeoning schemes for modern economic development mushroom despite a yawning local dearth of money, exploitable resources, infrastructure, wage labor, or even out-migration ([53], Chs. 11, 12).

Against the presumed progress of economic development, counterwaves of genealogical study by anthropologists and others are all the more important to expose the conditions, idiosyncracies, and contradictions that seed both the failure of such schemes and, at the same time, their political reinforcement and ideological intensification (e.g., [54-59]). As such, the critique of modern development is not over; indeed, it has hardly really begun. Associated here is the critical genealogy of modernist truth-claims, including the sequence and rationale of claims that modern planners make, often contrary to fact, about the viability of modern progress itself (cf., [60]). As discussed further below, it is arguably the presumption of modernist veridiction, its own deepseatedness as a taken-for-granted value, that is the root of its persistence-beyond either its objective impact on the world or its failure to deliver its longed-for results. In this regard, it seems highly important to distinguish potentially progressive dimensions of human improvement or progress from bequeathed ideologies that surround neoliberal modernity, including assumptions of and incitement to betterment through competitive 
individualism, minimal awareness of social and structural inequity, and utopian assumptions that everyone should and ultimately will have a better future and a better life [61-63].

\section{Anthropology in the Mix}

Current sensibilities in sociocultural anthropology are surprisingly congruent with several of the substantive designations made concerning genealogical investigation by Foucault in "Nietzsche, Genealogy, History" ([4], p. 89ff.). These include:

- Being highly sensitive to local specificity and context

- Unearthing circumstances of decadence and degeneration

- Working at the foot of lofty mountain peaks of influence "at the risk of adopting the famous perspective of frogs"

- Immersion in "barbarous and shameful confusion"

- Shortening vision to what is nearest to hand

- Becoming a practically "curative science" (cf., 'engaged anthropology') that supplies "differential knowledge of energies and failings, heights and degenerations, poisons and antidotes"

- Explicit in its perspective of acknowledging systems of injustice, including its own, reaching "the lingering and poisonous traces in order to prescribe the best antidote"

- "It is not given to a discreet effacement before the objects it observes and does not submit itself to their processes; nor does it seek laws, since it gives equal weight to its own sight and to its objects"

- Reflexively "composes a genealogy of history as the vertical projection of its position"

In parallel with this, anthropology in general and ethnography in particular are genealogically subversive by unearthing new, complex, often confusing but typically surprising or unnerving social and political realities in the most distinctive, unexamined, unusual, and yet regular of cultural places. This goes beyond subversion at the level of content, the genealogical subversion that Koopman ([1], p. 73ff.) finds in Nietzschean genealogies of the will to power. Genealogy for Foucault ([4], Chs. 3-6) is additionally subversive in problematizing the assumptions of knowledge behind the structuring of facts and sequences-critically exposing their deeper epistemic imposition and incitement. This more fundamental defamiliarization is thrown into relief by juxtaposing alternative lines of genealogical connection against those based on received assumptions.

As Owen ([64], p. 224, paraphrased) puts it, genealogical analysis:

1. Identifies a received picture which holds us captive, whereby this captivity obstructs our capacity to make sense of ourselves as agents in ways that matter to us;

2. Re-describes this picture in contrastive ways that frees us from this captivity;

3. Provides an account of just how we have become captive by received views, perspectives that hinder our ability to make of ourselves agents in ways we find important;

4. Motivates us to engage the practical working out of this re-orientation, including its relation to ourselves as agents.

The subversion of genealogical study is hence to show how received assumptions easily project a taken-for-granted past into a taken-for-granted future. This is arguably the central contradiction of modernity itself: an ideology that future time is new time and better time-neuzeit as modernity itself [65]. This hopefully better future is on the one hand unknowable and unpredictable and yet, on the other hand, expected, anticipated, and ultimately assumed to bring progress, a progress in which critiques are themselves subverted into ideology. The risk of modernity against its real-world compromise is hence both effaced and reintroduced by its very terms of assertion.

As Koopman notes ([1], Ch. 7), this is a practical and ethically engaged process as well as well as a theoretical one. For many anthropologists, it is also a sobering practical lesson concerning the limits of what they can do. Not that the juggernaut of modernity has caused anthropologists to be less critical 
or less practically engaged. Rather, I think, it has led anthropologists to more realistic appraisals of the relationship between critical thinking that is general, and real-world interventions that are practical and doable.

On the theoretical side, anthropology has by now largely recovered from the grand theoretical debates and diatribes of previous decades, including that between modernism and postmodernism during the 1980s and 90s. This is not so much an embraced depolarization as a tendency to shy away from big theoretical stances and their high-flying debates. Erstwhile contentions even between the asserted importance of theory itself and its empirical refutation-between deduction and induction-now seem to lack energy in the human sciences. In this sense, contemporary anthropology continues to be "post-paradigmatic" [66].

On the practical side, however, drawing on the legacies of critical humanitarianism, anthropologists are on the whole becoming increasingly keen to assess what they can do in the field as well as in the academy. The goal is not to 'save the world' but to make some concrete difference in the lives of others, even if relatively small or personal in scale. This either during fieldwork, helping people one has been studying among, or afterwards, including vis-à-vis students, colleagues, and other professionals or persons in power. These trends inform and reflect the enormous growth of so-called engaged anthropology in recent years (see overview in [67]).

Simply put, engaged anthropology is practical work and personal activism by an anthropologist on behalf of local people that takes seriously their own goals and aspirations ([53], Ch. 11; [68]). Typically, these engagements attempt to help marginalized or subordinated people pursue at least some of their own concrete plans or desires in areas such as economic development, health, education, security, or politics. Long an informal or personal aspect of fieldwork, engaged anthropology has in recent years become one of cultural anthropology's greatest new areas of explicitly promulgated professional practice, research, publication, and recognition.

Suspended between analytically informed critique and concrete social action, engaged anthropology is integral to what I have elsewhere termed "anthropology in the middle"-a contemporary anthropology balanced in creative tension between erstwhile poles of local versus regional or global scale, historicism versus presentism, critique versus empiricism, and theoretical analysis versus practical engagement and application [66]. These engagements reflect the coming out of the closet of activism and advocacy as part of anthropologists' professional as well as their personal roles and scholarly mandates. Anthropologists have long been activist, but the presentation and acceptance of such commitments as part and parcel of one's professional persona has increased significantly in recent years.

\section{Limitations and Revisitations: Beyond the Suffering Subject?}

The limit points of a Foucauldian genealogical perspective in anthropology deserve examination. Though many anthropologists identify with the genealogical dispositions that are bullet-pointed further above, few of them would explicitly consider themselves intellectual descendants of a Foucauldian intellectual genealogy. Why?

First, the nominalism of Foucault, his search for an genealogy of veridictions, can seem rarefied and removed from the daily pragmatics of social life. Notwithstanding Foucault's emphasis on bodily politics and on institutions of discipline and governmentality, practical features of social life at varying levels of personal and collective scale-particularly in non-Western contexts-are not central to Foucault's agenda. The activist strains of contemporary anthropology are hence at odds with those moments of Foucault's work that carry an aura of detached understanding if not Olympian omniscience. These seem removed from pressing realities in the ethnographic trenches-in which anthropologists grapple with the fraught lives and challenges of otherness. Additionaly, Foucault's genealogical method requires such historical erudition - and is used with such scope, creativity, and power by Foucault himself- - that it is not always easy for others to borrow or reproduce his perspective effectively. Like Max Weber-who also originated one of the 20th century's powerful new forms of 
intellectual discursivity [3]-Foucault's method is often easier to draw insights from at the level of either content or epistemology than to use as a full template for one's own concrete analysis.

It is here that revisiting the more specific content of Nietzschean genealogy-and its anthropological application-may be useful. Though Foucault pays passing homage to the fact that "Nietzsche's version of historical sense is explicit in its perspective and acknowledges its system of injustice" ([4], p. 90), the kind of injustice that Nietzsche legitimates and indeed champions has elitist if not Trumpian undertones that are generally critiqued rather than favored in contemporary anthropology. Rather than Nietzschean ressentiment by the weak plebian masses that has to be overcome by the pure art of aristocratic will and imposition — the will to power by the dominant-the nagging demand of equality from below is the paragon rather than the nadir of anthropology's respect for, admiration of, and assistance to the subalterns that it frequently studies. Bluntly put, anthropologists tend to foreground and champion the wretched of the earth rather than denigrating and dismissing them (cf., [69]).

A revealing and highly influential interpretation of this tendency in anthropology, including its potential excesses as well as alternatives, was recently published by Joel Robbins. In "Beyond the Suffering Subject: Toward an Anthropology of the Good" [33], Robbins delineates the tendency-cum-axiom of anthropologists to focus on, lament, and critique the disenfranchisement and disempowerment of people vis-à-vis those who exert superiority over them. Robbins is nuanced in his portrayal, and, like most anthropologists, he is at the opposite pole from Nietzsche's withering criticism of ressentiment by subalterns against their real or imagined superiors. Robbins' critique does, however, does adduce important parallels with Nietzsche, if in significant part through inversion.

Robbins argues that the central subject of anthropology from the late 1980s until recently has been the victimization of and sympathy for the oppressed. From within a Nietzschean perspective, it is not much of a stretch to see this as the actualization of Nietzsche's greatest fear-that the elite heights of self-willed and artistic accomplishment will be co-opted, subverted, and downgraded to their lowest and most plebian common denominator. The flipside of this argument, of course, is the anthropological critique of Nietzsche himself, who could be viewed, as mentioned above, as a bigoted elitist and pernicious anti-humanist.

Robbins' critique of anthropologists' own tendency-their strong drive to document and empathize with the trials and victimization of suffering subjects-is further revealing. It resonates effectively with what eminent anthropologist Sherry Ortner [70] has criticized as "resistance and the problem of ethnographic refusal". This is the tendency for anthropologists' understanding of other peoples and cultures to be thinned and flattened out by the assumption that others' concerns revolve primarily around being exploited and dominated, on the one hand, and resisting this domination, on the other. Though these are undeniably important, key parts of social life, they are not necessarily its heart, its self-perceived reason for being, or its overall modus operandi.

Neither Robbins nor Ortner in any way champions a Nietzchean elitist alternative; far from it. In Robbin's case, he stresses the alternative import of what he calls an Anthropology of the Good, that is, "to explore the different ways people organize their personal and collective lives in order to foster what they think of as good..." ([33], p. 457). This directs anthropological attention to understanding, documenting, and appreciating the constructs, beliefs, and practices of what is considered valuable, timely, empathetic, ethical, and moral or caring among different peoples and cultures. As such, the light of analysis is used to illuminate others' positive dispositions or values, and it emphasizes greater appreciation of the deep power of cultural belief, conditioning, and world-view. In the process, cultural diversity is re-valorized rather than being demoted to a potential afterthought of human oppression, victimization, and associated resistance or ressentiment. As such, as emphasized in another important article by Ortner [71], the anthropology of the good is the flipside or complement-rather than the simple replacement-of what she calls "dark anthropology", that is, anthropology that focuses on the harsh dimensions of social life, such as power, domination, inequality, and oppression. 
In one important way, however, Robbins' notion of the "good" remains very similar to the "good" that Nietzsche himself develops as the paragon of an elevated humanity. This is not the "good" described by Nietzsche as defined only negatively, by contrast to what is considered evil [72,73]. Rather, it the good that is "beyond good and evil"- the "good" that is self-standing, in contrast to the "bad". Though the point could be pushed too far, one might say that both Nietzsche and the important new trend in anthropology that Robbins nominates entail a willful assertion of what is culturally good and best rather than reductively defining this through and against the negativity of ressentiment.

The contrast between these respective vantage points seems important and instructive. Whereas Nietzsche's notion of the elevated and artistic "good" is the will to power of himself and his Greek-cum-German heritage-over and against all subaltern others-for Robbins, the anthropology of the good focuses on documenting others' views and practices on their own terms; it is resolutely relativist rather than absolutist.

Cultural relativism is of course one the most important touchstones of anthropology-and it has been for well over a century, virtually since the beginnings of the field as an academic discipline. This considerably complicates-and arguably enriches-post-Foucauldian notions of genealogy.

Perhaps in the same way that family tree and genealogy studies in popular Western culture empower individuals to appreciatively ferret out new ancestral roots, so anthropologists are charged to discover new genealogies, including the genealogy of what has been considered good and positive among alternative peoples and cultures. This pursuit is dependent on the fragmentary particularities, idiosyncrasies, and sequences of the past, as Foucault emphasized. Among other things, this awareness itself helps guard against a Pollyanna view that would simply replace a one-sided negative view of the human condition-the subject that is essentially suffering - with one that is one-sidedly positive-the subject that is inexorably trying to assert goodness. In the mix, this perspective narrows and grounds Foucault's tendency during his earlier and mid-career works to grind up the complex diversity of lived human experience into superordinate epistemic if not ontological regimes of power.

In anthropology more generally, genealogy studies in a new key can facilitate rigorous investigative journalism at the level of content and history, providing deep and searching critiques of received popular-and theoretical—assumptions. It resonates especially with Foucault's final works, particularly the last two volumes of the History of Sexuality $[74,75]$ and his related papers and interviews on the genealogy of ethics and technologies of the self [76,77]. More akin to current developments in sociocultural anthropology, these works are nuanced applications of genealogical method to illuminate subjectivities of ethical self-relationship—how the self is constituted as an ethical subject-in specific alternative cultural and historical contexts.

\section{Limitations, Examples, and Hopes in Higher Register}

Lest such a selective appreciation of-and departure from-Nietzsche and Foucault be taken too simply as a grounding point for a newly genealogical anthropology, some caveats should be registered. First, the radical pluralization of genealogies-potentially from each culture if not from each individual within them-raises the question of what might be called 'intergenealogy': how can highly diverse genealogies be themselves framed within a larger optic of understanding? The terms of 'genealogy' - the units to be connected and their mode of lineal connection or 'descent' over time-may be highly variable from case to case and but loosely applied across a field of interest. Relatedly, genealogical critique risks defining itself negatively, by subverting and rendering problematic one or another received view of history or culture, rather than providing a positive alternative with its own strategy of articulation. Though this may be less of a problem when engaged through general or abstract criteria of genealogical understanding, it emerges more strongly when applying genealogical methods concretely to world-diverse sociocultural phenomena (e.g., [78]). In method, genealogy studies may be as powerful as they are potentially diverse, unsystematic, or non-comparable.

From an anthropological perspective, philosophical parameters for articulating critical theory and pragmatism with genealogical study, as suggested by Koopman [1], tend to remain at high levels of 
conceptual remove from ethnographic and historical specifics. Detailed historical, ethnographic, and other contemporary case studies-of the kind that Foucault endeavored to illustrate, including toward the end of his life-would be very welcome. Ensuing articles in the present journal will presumably explore such possibilities.

To take a concrete example, one could consider the genealogical pattern of descent in American presidential politics that has most recently lead to the election of Donald Trump as POTUS. Adding to the disjunctive relation between Trump and Obama as his predecessor is the fact that virtually all the major news media failed miserably to predict the election results even just ahead of time. This suggests that their tracking of the chain of voter opinions leading up to election day was biased, a liberal genealogical over-projection of a Hillary Clinton presidency based on Obama's presumed legacy. An anthropological and specifically ethnographic understanding of the deeper levels and contours of voter discontent could have countermanded this skewing, getting beneath the simplistic answers elicited from eligible voters by pollsters' crude questions about whether they were leaning to vote for Trump versus Clinton. As suggested by Geuss ([79], p. 67), alternative genealogies of the present per Foucault provide "a way of concentrating attention on a given situation in the context of an imminent danger... Genealogy does not lay down the law, nor is it a policing discipline. Rather it is a summons to develop an empirically informed kind of theoretical imagination under conditions of danger". Or, as Bové ([80], p. xxvii) puts it in his forward to Deleuze's Foucault, a war of position à la Gramsci "cannot by itself serve as an adequate guide to opposition since, in effect, it insists upon inscribing itself as a reflection of what it hopes to negate or transcend" and hence "is an inadequate reflection of the dispersed and unequal effects of power...". In the present, this begs the 21st century relation between older forms of collective social movement or unionization, and newer forms of rhizomatic connection that are creatively orthogonal to received contours of self-hood in power, and that operate by critically energizing the "folds" or "zones of subjectivation" that play with and from the "inside of thought" ([81], p. 120ff). These are arguably tools of social and intellectual engagement that will be important, for instance, in months and years ahead in the US as the legacy of Trump's election plays out.

Applying this sensibility, different ways become possible to trace Trump's ascendence genealogically. In received views of political succession, one could view Trump's election as simply another turn of the ongoing cycle of alternation between Democratic and Republican Presidencies. In a different optic of sequencing, however, Trump's election betokens a decisive shift to American political authoritarianism-perhaps akin to the devoltion in Ancient Rome from a Republican to an Imperial period (cf., [82]). In complementary perspective, Trump's election may mark not a rupture but a genealogical continuity: the intensification and solidification of privatized neoliberalism at the expense of collective government (cf., [63]). In the process, the interests of the wealthy not only trump those of those of the common good but are legitimated ideologically to such an extent that they become promulgated through the so-called democratic proceses itself. In such a climate of hegemonic encompassment, as alluded to above, older models of resistance through oppositional party politics or rank-and-file social movements beg deeper awareness and resistance-what Deleuze [81] describes as creative awareness of the folds of power. Critically reflective experience of these involuted borders of the weighty subjective interiorities of power can help reveal their limit points, how they ultimately contain the seeds of their own externalization and extrusion [83].

How to productively develop countermainstream readings of our current condition clearly calls for subtlety in political genealogy as suggested by Michael Clifford ([47], p. 108; cf., [84]): "So what are the components of political genealogy? That depends on what is being subjected to genealogical critique. We have already alluded to at least a few general categories of inquiry: discourse and discursive formations, power relations, and modes of subjectivation, enunciative modalities, and even geography. But, and this is very important, these categories will be different depending on that aspect or cultural phenomenon that is the focus of historical critique". For Clifford, three axes of political 
genealogy follow the received triumvirate of Foucauldian concerns: truth, power, and self-relationship, each of which parses a distinct genealogical thread or aspect of critique (see also [85]).

Political genealogy is a powerful form of analysis, but as Clifford ([47], p. 123) also notes, "Treatises on methodology can be frustratingly abstract. This is especially true of political genealogy because it refuses to appeal to transcendental principles or structural constraints". As such, political genealogy is intrinsically diversifying: "I do not believe that a history of the present can be accomplished by one or even a few genealogists, however masterful they might be at their craft". As such, commonly adduced strategies of genealogical analysis-reversal, discontinuity, specificity, and exteriority (see [86], Ch. 2)-are themselves diversely applied in analysis and not subject to definitive or normalizing modes of application.

To be effective in a contemporary political context, political genealogy can also track the sequence and superimposition of truth claims in assumedly authoritative media, history, or science-and juxtapose these to the lineal sequence and causal connection of assumed reasoning in prominent popular assertions to the contrary. For instance, the idea among many in rural American culture that global warming is a government plot, that immigrants are mostly rapists and criminals, or, per Donald Trump, that Hillary Clinton was a founder/fomenter of the Islamic State, or that President Obama is not a legal U.S. citizen. This relates more generally to the role of lies and deception in the current American electoral politics, or, more accurately, to what could or should be taken to be a lie, as opposed to other forms of constructed and asserted truth. The helix of these contrastive genealogies could be highly illuminating and instructive to chart, not simply to assert the veracity of one versus line of presumed factural connection vis-à-vis the other but rather to show the relationships, and the stakes, between their competing truth claims. A contrastive genealogical analysis of such helical trends would help expose and diagnose not just the ills of modernity-how our addiction to betterment is not just self-defeating but ultimately self-denigrating-but how common incitements to combat regressive politics can ulimately reinforce both their existence and their seeming inevitability. This starts to illuminate how the pathology of that thing called modernity is intrinsic to the very assumptions and generalized values upon which it is based—and through which it appears so refractory to being effectively resisted or overturned (cf., [60-62,87]).

Finally, one could conduct an inter-genealogical analysis of the above broad trajectories. In what ways is the apparent current penchant for blatant political lying an exemplification or inflection of an underlying crisis of modernity, the failure of tropes of betterment that fuel an anti-modern modernism of ressentiment within the U.S.- as reflected in increased authoritarianism and the ascendance of reactionary neoliberalism? Given that the U.S. and its corporate imperialism are still taken by many as a paragon of modern development (see [82]), what does this indicate about the stresses, crisis, or, as David Harvey ([88], Ch. 27) might put it, the cracks in the mirror of the future of modernity itself?

\section{Caveat Emptor}

As further exploration of the above examples would reveal, genealogical analysis is not an easy or simple task; it requires a high degree of erudition as well as practical sensitivity. Even in an "Anthropology of the Good", genealogies would potentially include the lineal connection between beliefs and applications of value within and across wide-ranging cultures, and, even, individuals. The power of genealogies to render existing lines of connection problematic-as foregrounded by Foucault, highlighted by Owen [64] and reanalyzed by Koopman [1]—is easily complemented by their imprecision and potential incommensurability, both in structure of temporal sequence and concerning the units that are taken to inform or 'bequeath' connections over time. Exactly what is it that 'begets', what is 'begot' over time? And by what process of articulation does this take place?

At the extreme, genealogy becomes a method rather than a theory: by itself, it theorizes neither the units of analysis that are linked in lineal sequence nor their manner of articulation. In the same way that a genealogical tree is defined by kinship - who is 'related' to who is a function of culture and not just of biology (or of our present biogenetic representation), so, too, the terms and assumptions of genealogy 
beg a host of analytic, theoretical, and definitional questions. These presumably would and should vary greatly depending on the empirical, historical or conceptual context to which genealogical analysis is applied. Genealogical subversion is defined to some extent negatively against and around the strictures of received understanding. But how—and to what degree — can this also be done through positive definition to allow for concrete application across cases, and comparatively across different kinds of genealogical analyses in different? Some of the prominent recent attempts at genealogical analysis in anthropology (e.g., $[89,90]$ ) continue, in contrast to Foucault's own last works, to be ethnographically rarified, theoretically dense, and self-referentially involuted, as a result of which they have not been particularly influential in anthropology as a whole.

Perhaps a positive dimension of this process is greater flexibility in seeing the value as well as the cost of analogic or metaphoric associations among and between different kinds of genealogical assertions or connections. At least in cultural anthropology, the 'realist' moment of the early-to-mid 20th century is decidedly past. By the late 1980s and 1990s, terms of categorical attribution were often put in 'scare quotes' - that is, to signal that the concept in question functioned under erasure (see [91], Ch. 4). Terms could be used only 'heuristically', permeated by self-consciousness that concepts are not labels of objectivity that refer transparently to independently existing things in the world. But since the 1990s, anthropology and other human sciences have increasingly taken off the scare quotes and lightened up, with a greater playfulness and panache concerning terms of reference. Increasingly, conceptual cover terms function in referential designation without being assumed to have fixed and absolute truth value. This has helped facilitate a burgeoning new generation of topics for anthropological investigation and analysis (see [92]; cf., [93]).

Flexibility of reference both subverts and selectively reincorporates or redefines older categories, debates, and perspectives-in a newly creative and sometimes ironic if certainly not 'higher' key. As such, the specificity, creativity, and flexibility that attend genealogical analysis engages new and innovative topics of critical interest to contemporary anthropology. As Baudelaire would remind us, and as Deleuze would reinforce, amid the dizzying complexities of a contemporary world, we have no right to despise either the circumstances of the present or modes of our representation that exceed stark positivist reference.

The larger hope and expectation would seem to be that freshly considered optics of genealogy can illuminate newly critical and creative linkages between otherwise diverse, disparate, or incommensurable phenomena-as Kretsedemas suggests in his inaugural editorial for this journal. In this sense, the larger hope of genealogy studies is meta, leading potentially to reflexive awareness concerning the genealogy of our own genealogies. If the creativity, connection, and subversive power of genealogies is in the hands of their users and definers-this being both their strength and their limitation-these would seem integral to the great potentials as well as to the limitations of the present new project.

Conflicts of Interest: The author declares no conflict of interest.

\section{References and Notes}

1. Koopman, Colin. Genealogy as Critique: Foucault and the Problems of Modernity. Bloomington: Indiana University Press, 2013.

2. Baudelaire, Charles. The Painter of Modern Life and Other Essays. London: Phaidon, 1970.

3. Rabinow, Paul. "Introduction." In The Foucault Reader. Edited by Paul Rabinow. New York: Vintage Books, 1984, pp. 3-29.

4. Foucault, Michel. The Foucault Reader. Edited by Paul Rabinow. New York: Pantheon, 1984.

5. Lightbody, Brian. Philosophical Genealogy: An Epistemological Reconstruction of Nietzsche and Foucault's Genealogical Method. New York: Peter Lang, 2010, vol. 1.

6. Lightbody, Brian. Philosophical Genealogy: An Epistemological Reconstruction of Nietzsche and Foucault's Genealogical Method. New York: Peter Lang, 2011, vol. 1.

7. Fox, Robin. Kinship and Marriage. New York: Penguin, 1967. 
8. Lévi-Strauss, Claude. The Elementary Structures of Kinship. Translated by Rodney Needham. Boston: Beacon, 1969.

9. Murdock, George Peter. Social Structure. New York: Free Press, 1949.

10. Sahlins, Marshall. What Kinship Is-And Is Not. Chicago: University of Chicago Press, 2013.

11. Talal Asad, ed. Anthropology and the Colonia Encounter. Atlantic Highlands: Humanities Press, 1973.

12. James Clifford, and George E. Marcus, eds. Writing Culture: The Poetics and Politics of Ethnography. Berkeley: University of California Press, 1986.

13. Clifford, James. The Predicament of Culture: Twentieth-Century Ethnography, Literature, and Art. Cambridge: Harvard University Press, 1988.

14. Stocking, George W., Jr. Victorian Anthropology. New York: Free Press, 1987.

15. Stocking, George W., Jr. The Ethnographer's Magic and Other Essays in the History of Anthropology. Madison: University of Wisconsin Press, 1992.

16. Stocking, George W., Jr. After Tylor: British Social Anthropology, 1888-1951. Madison: Wisconsin University Press, 1995.

17. Paul Bohannon, and Mark Glazer, eds. High Points in Anthropology, 2nd ed. New York: McGraw-Hill, 1988.

18. Knauft, Bruce M. Genealogies for the Present in Cultural Anthropology. New York: Routledge, 1996.

19. Peletz, Michael. "Kinship Studies in Late 20th-Century Anthropology." Annual Reviews in Anthropology 24 (1995): 343-72. [CrossRef]

20. Bodenborn, Barbara. "The Anthropology of Kinship: The Kinship of Anthropology." In The Handbook of Sociocultural Anthropology. Edited by James G. Carrier and Deborah Gewertz. London: Bloomsbury, 2013, pp. 137-55.

21. Weston, Kath. Families We Choose: Lesbians, Gays, Kinship. New York: Columbia University Press, 1997.

22. Reddy, Gayatri. With Respect to Sex: Negotiating Hijra Identity in South India. Chicago: University of Chicago Press, 2005.

23. Hannaford, Dinah. Marriage without Borders: Transnational Spouses in Neoliberal Senegal. Philadelphia: University of Pennsylvania Press, 2017.

24. Franklin, Sarah. Biological Relatives: IVF, Stem Cells, and the Future of Kinship. Durham: Duke University Press, 2013.

25. Appadurai, Arjun. Modernity at Large: Cultural Dimensions of Globalization. Minneapolis: University of Minnesota Press, 1996.

26. Kuper, Adam. The Invention of Primitive Society: Transformations of an Illusion. London: Routledge, 1988.

27. McLennan, John M. Primitive Marriage: An Inquiry into the Origin of the Form of Capture in Marriage Ceremonies. Edinburgh: Black, 1865.

28. McLennan, John M. Studies in Ancient History. London: Quaritch, 1876.

29. Maine, Henry. Ancient Law. London: John Murray, 1861.

30. Maine, Henry. Lectures on the Early History of Institutions. London: John Murray, 1876.

31. Morgan, Lewis Henry. Systems of Consanguinity and Affinity of the Human Family. Washington: Smithsonian Institute, 1871.

32. Morgan, Lewis Henry. Ancient Society: Researches on the Lines of Human Progress from Savagery through Barbarism to Civilization. New York: Holt, 1877.

33. Robbins, Joel. "Beyond the Suffering Subject: Toward an Anthropology of the Good." Journal of the Royal Anthropological Institute 19 (2013): 447-62. [CrossRef]

34. Marcus, George E., and Michael Fischer. Anthropology as Cultural Critique: An Experimental Moment in the Human Sciences. Chicago: University of Chicago Press, 1986.

35. Knauft, Bruce M. "Pushing Anthropology past the Posts." Critique of Anthropology 14 (1994): 117-52. [CrossRef]

36. Miller, James. The Passion of Michel Foucault. New York: Simon and Schuster, 1993.

37. Eribon, Didier. Michel Foucault. Cambridge: Harvard University Press, 1991.

38. May, Todd. The Philosophy of Foucault. Chesham: Acumen, 2006.

39. Said, Edward W. "Michel Foucault, 1926-1984." In After Foucault. Edited by Jonathan Arac. New Brunswick: Rutger's University Press, 1988, pp. 1-11.

40. Mills, Sara. Michel Foucault. London: Routledge, 2003.

41. Macey, David. Michel Foucault. London: Reaktion Books, 2004. 
42. François Callat, ed. Foucault against Himself. Vancouver: Arsenal Pulp Press, 2015.

43. McGushin, Edward F. Foucault's Askesis: An Introduction to the Philosophical Life. Evanston: Northwestsern University Press, 2007.

44. Harvey, David. Saint Foucault: Towards a Gay Hagiography. Oxford: Oxford University Press, 1997.

45. Williams, Bernard. Truth and Truthfulness: An Essay in Genealogy. Princeton: Princeton University Press, 2004.

46. Jensen, Anthony K. Nietzsche's Philosophy of History. Cambridge: Cambridge University Press, 2013.

47. Clifford, Michael. Empowerment: The Theory and Practice of Political Genealogy. Lanhamn: Lexington Books, 2013.

48. Nietzsche, Friedrich. On the Genealogy of Morals. New York: Penguin, 2013.

49. Smith, Douglas. "Introduction." In On the Genealogy of Morals. Edited by Friedrich Nietzsche. Oxford: Oxford University Press, 2008, pp. vi-xxxi.

50. Foucault 17 January 1979 lecture on the "Birth of Biopolitics".

51. Foucault, Michel. "Society Must Be Defended": Lectures at the College de France, 1975-1976. New York: Picador, 2003.

52. Bruce M. Knauft, and Richard Taupier, eds. Mongolians after Socialism: Politics, Economy, Religion. Ulaanbaatar: Admon Press, 2012.

53. Knauft, Bruce M. The Gebusi: Lives Transformed in a Rainforest World, 4th ed. Long Grove: Waveland Press, 2016.

54. Escobar, Arturo. Encountering Development: The Making and Unmaking of the Third World. Princeton: Princeton University Press, 1995.

55. Ferguson, James. Expectations of Modernity: Myths and Meanings of Urban Life on the Zambian Copperbelt. Berkeley: University of California Press, 1999.

56. Mosse, David. Cultivating Development: An Ethnography of Aid Policy and Practice. London: Pluto, 2005.

57. David Mosse, and David Lewis, eds. The Aid Effect; Giving and Governing in International Development. London: Pluto, 2005.

58. Li, Tanya. The Will to Improve: Governmentality, Development, and the Practice of Politics. Durham: Duke University Press, 2007.

59. Li, Tanya. Land's End: Capitalist Relations on an Indigenous Frontier. Durham: Duke University Press, 2014.

60. Bruce M. Knauft, ed. Critically Modern: Alternatives, Alterities, Anthropologies. Bloomington: Indiana University Press, 2002.

61. Giddens, Anthony. The Consequences of Modernity. Stanford: Stanford University Press, 1990.

62. Giddens, Anthony. Modernity and Self-Identity: Self and Society in the Late Modern Age. Stanford: Stanford University Press, 1991.

63. Harvey, David. A Brief History of Neoliberalism. Oxford: Oxford University Press, 1997.

64. Owen, David. "Criticism and Captivity: On Genealogy and Critical Theory." European Journal of Philosophy 10 (2002): 216-30. [CrossRef]

65. Kosselleck, Reinhart. Futures Past: On the Semantics of Historical Time. Cambridge: MIT Press, 1985.

66. Knauft, Bruce M. “Anthropology in the Middle." Anthropological Theory 6 (2006): 407-30. [CrossRef]

67. Low, Setha M., and Sally Engle Merry. "Engaged Anthropology: Diversity and Dilemmas." Current Anthropology 51 (2010): S203-S26. [CrossRef]

68. Knauft, Bruce M. "Engaged Anthropology: Out of the Closet? Anthropology Roundtable Presentation." Atlanta: Emory University, 2015. (posted on the author's website).

69. Fanon, Frantz. The Wretched of the Earth. New York: Penguin, 1968.

70. Ortner, Sherry. "Resistance and the Problem of Ethnographic Refusal." Comparative Studies in Society and History 37 (1995): 173-93. [CrossRef]

71. Ortner, Sherry. "Dark Anthropology and its Others: Theory since the Eighties." Hau: Journal of Ethnographic Theory 6 (2016): 47-73. [CrossRef]

72. Nietzsche, Friedrich. Beyond Good and Evil: Prelude to a Philosophy of the Future. New York: Vintage, 1966.

73. Nietzsche, Friedrich. Thus Spoke Zarathustra. New York: Viking, 1954.

74. Foucault, Michel. The Use of Pleasure. New York: Vintage, 1985.

75. Foucault, Michel. The Care of the Self. New York: Vintage, 1986. 
76. Foucault, Michel. "Technologies of the Self." In Technologies of the Self: A Seminar with Michel Foucault. Edited by Luther H. Martin, Huck Butman and Patrick H. Hutton. Amherst: University of Massachusetts Press, 1988, pp. 16-49.

77. Foucault, Michel. “On the Genealogy of Ethics: An Overview of Work in Progress." In The Essential Works of Foucault, 1954-1984, Volume 1: Ethics, Subjectivity, and Truth. Edited by Paul Rabinow. New York: Free Press, 1997, pp. 253-80.

78. Knauft, Bruce M. "Moments of Knowledge and Power: Foucault and the Alterities of Sex and Violence." In Genealogies for the Present in Cultural Anthropology. Edited by Bruce Knauft. New York: Routledge, 1996, pp. 141-76.

79. Geuss, Raymond. “Genealogy as Critique.” In Michel Foucault. Edited by David Owen. Farnham: Ashgate, 2014, pp. 63-69.

80. Bové, Paul. "Forward: The Foucault Phonomenon: The Problematics of Style." In Foucault. Edited by Gilles Delueze. Minneapolis: University of Minneapolis Press, 1988, pp. vii-xl.

81. Deleuze, Gilles. Foucault. Minneapolis: University of Minneapolis Press, 1988.

82. Knauft, Bruce M. "Provincializing America: Imperialism, Capitalism, and Counter-hegemony in the Twenty-first Century." Current Anthropology 48 (2007): 781-805. [CrossRef]

83. Deleuze, Gilles, and Félix Guattari. A Thousand Plateaus: Capitalism and Schizophrenia. Minneapolis: University of Minnesota Press, 1987.

84. Clifford, Michael. Political Genealogy after Foucault: Savage Identities. New York: Routledge, 2001.

85. Mahon, Michael. Foucault's Nietzschean Genealogy: Truth, Power, and the Subject. Albany: State University of New York Press, 1992.

86. Shumway, David R. Michel Foucault. Boston: Twayne/G.K. Hall \& Co., 1989.

87. Berman, Marshall. All that Is Solid Melts into Air: The Experience of Modernity. New York: Penguin, 1982.

88. Harvey, David. The Condition of Postmodernity: An Enquiry into the Origins of Culture Change. Cambridge: Blackwell, 1989.

89. Rabinow, Paul, and Anthony Stavrianakis. Designs on the Contemporary: Anthropological Tests. Chicago: University of Chicago Press, 2013.

90. Rabinow, Paul, George Marcus, James D. Faubion, and Tobias Rees. Designs for an Anthropology of the Contemporary. Durham: Duke University Press, 2008.

91. Visker, Rudi. Michel Foucault: Genealogy as Critique. New York: Verso, 1995.

92. Knauft, Bruce M. "Issues in Sociocultural Anthropology since the Sixties." In The Handbook of Sociocultural Anthropology. Edited by James G. Carrier and Deborah Gewertz. London: Bloomsbury, 2013, pp. 229-328.

93. James G. Carrier, and Deborah Gewertz, eds. The Handbook of Sociocultural Anthropology. London: Bloomsbury, 2013.

(c) 2017 by the author; licensee MDPI, Basel, Switzerland. This article is an open access article distributed under the terms and conditions of the Creative Commons Attribution (CC-BY) license (http://creativecommons.org/licenses/by/4.0/). 